\title{
Changes in Respiration Rate and Energy of Activation after Chilling and Forcing Dormant Apple Trees
}

\author{
Eric Young ${ }^{1}$ \\ Department of Horticultural Science, North Carolina State University, Raleigh, NC 27695 \\ Additional index words. Malus domestics, budbreak, root growth, temperature, $\mathrm{Q}_{10}$
}

\begin{abstract}
Dormant apple trees (Malus domestics Borkh., CV. MM. 111) were chilled at SC for O, 500, 1000, or 1500 hours and then forced at 10, 20, or 30C for 21 days. Budbreak and root growth were recorded after forcing, and shoot and root respiration was measured at 5, 10, 20, and 30C to determine $Q_{10}$ and energy of activation values. Budbreak, root growth, and respiration generally increased with chilling and forcing temperature. The $Q_{10}$ of shoot respiration increased significantly with increasing chilling when measured before forcing; however, after forcing, $Q_{10}$ decreased with chilling. Root respiration $Q_{10}$ was not as influenced as shoot respiration by chilling either before or after forcing. Energy of activation for shoot and root respiration decreased significantly with chilling after forcing at each temperature.
\end{abstract}

Deciduous fruit trees require a minimum amount of chilling (4 to 10C) for release from dormancy (Perry, 1971; Samish, 1954) and initiation of growth. This transition from dormancy to active growth is accompanied by many metabolic changes, some of which are temperature-regulated, DNA and RNA levels increase significantly in chilled buds (Batskaya and Oknina, 1959). Protein content decreases in the bark (Titus and Kang, 1982) and increases in the buds (Wang et al., 1985). Hormone levels change dramatically, with inhibitors generally decreasing and promoters increasing (Wood, 1983), and polyamides increase rapidly at the' end of dormancy (Wang et al., 1985). Amino acid content of shoots increases during early spring growth and is correlated with the decrease in bark proteins (Titus and Kang, 1982). Carbohydrate levels change as reserves are broken down and mobilized for new shoot and root growth (Quinlan, 1969; Hansen, 1971).

-Woody perennials have a high level of degradable carbohydrate reserves (Priestly, 1962) that are unlikely to be exhausted under normal circumstances. Nevertheless, many trees demonstrate a marked seasonal 'fluctuation in respiration rate when measured at constant temperature. These fluctuations have been reported in shoots and roots of Populus (Cox, 1975), Pinus (Shiroya et al., 1966), and other species (Strain, 1969). Holthausen and Caldwell (1980) found seasonal changes in root respiratory capacity of Atriplex, with peak capacity occurring in spring. This increase was not correlated with soil temperature or moisture and might reflect an environmental preconditioning. Butler and Landsberg (1981) reported that respiration rates of apple branches at a given temperature were low during dormancy, rose rapidly to a peak in spring, and then declined steadily through the season. Wang et al. (1985) found a significant increase in respiration of apple buds induced to break dormancy by thidiazuron compared to untreated buds. Young et al. (1987) showed that respiration of apple root and shoot tissue increased after 30 days at $23 \mathrm{C}$ only after trees had been fully chilled. Also, further chilling resulted in even greater increases after the

Received for publication 15 Dec. 1989. Paper no. 12501 of the Journal Series of the N.C. Agr. Res. Serv., Raleigh, NC 27695. I acknowledge the valuable technical assistance of Robert Belding throughout this study. The cost of publishing this paper was defrayed in part by the payment of page charges. Under postal regulations, this paper therefore must be hereby marked advertisement solely to indicate this fact.

I Professor. same forcing time. It appears that chilling during dormancy preconditions the tree for metabolic response at a higher rate when placed at temperatures that promote growth. A similar situation has been documented for dormant seeds, where Avena seeds that had been stratified before imbibition showed a 4-fold increase in respiration compared to unstratified seed (Chen and Varner, 1970).

Because respiration increased significantly in apple trees moved from 5 to 23C only after chilling was complete (Young et al., 1987), chilling appeared to lead to a change in the temperature response curve for respiration; i.e., a change in the respiration $\mathrm{Q}_{10}$, which would also indicate a change in the energy Of activation. The objective of this study was to determine if chilling dormant apple trees has an effect on the temperature response of shoot and root respiration. Also, the effect of several forcing temperatures after chilling was investigated.

\section{Materials and Methods}

One-year-old rooted layers from a commercial stoolbed (Oregon Rootstock, Woodburn, Ore.) of Mailing Merton 111 (MM.111) apple [chilling requirement 1140 chill units (CU)] were lifted from the nursery after accumulating $<100 \mathrm{CU}$. All trees were pruned to $45 \mathrm{~cm}$ above the root collar and all lateral branches removed, which left eight to 10 buds per tree. Trees were placed in a cold room at $5 \pm 2 \mathrm{C}$ with their roots in moist sphagnum and wrapped to avoid desiccation. After 0, 500, 1000, or $1500 \mathrm{hr}$ of chilling, 48 trees were removed. Thirty-six trees were potted in 3.5-liter containers in damp calcined clay (Turface) and 12 potted trees were placed in each of three growth chambers at 10,20 , or $30 \mathrm{C}$ (forcing temperatures) for 21 days under 16-hr photoperiods. Root and shoot respiration were measured immediately on the remaining 12 trees according to procedures described below. After 21 days of forcing, potted trees were carefully removed from pots, number of broken buds counted, and new root growth rated ( 1 to $5,1=$ no new roots, $3=$ new roots distributed through half of the old roots, $5=$ new roots distributed throughout all old roots) before respiration was determined. All trees were cut at the root collar and any new shoot growth was removed before respiration was measured. All shoots were cut into three pieces and roots carefully bent to fit into $100-\mathrm{ml}$ test tubes. Previous tests showed that this

$\overline{\text { Abbreviations: }} \mathrm{CU}$, chilling units; Ea, energies of activation. 


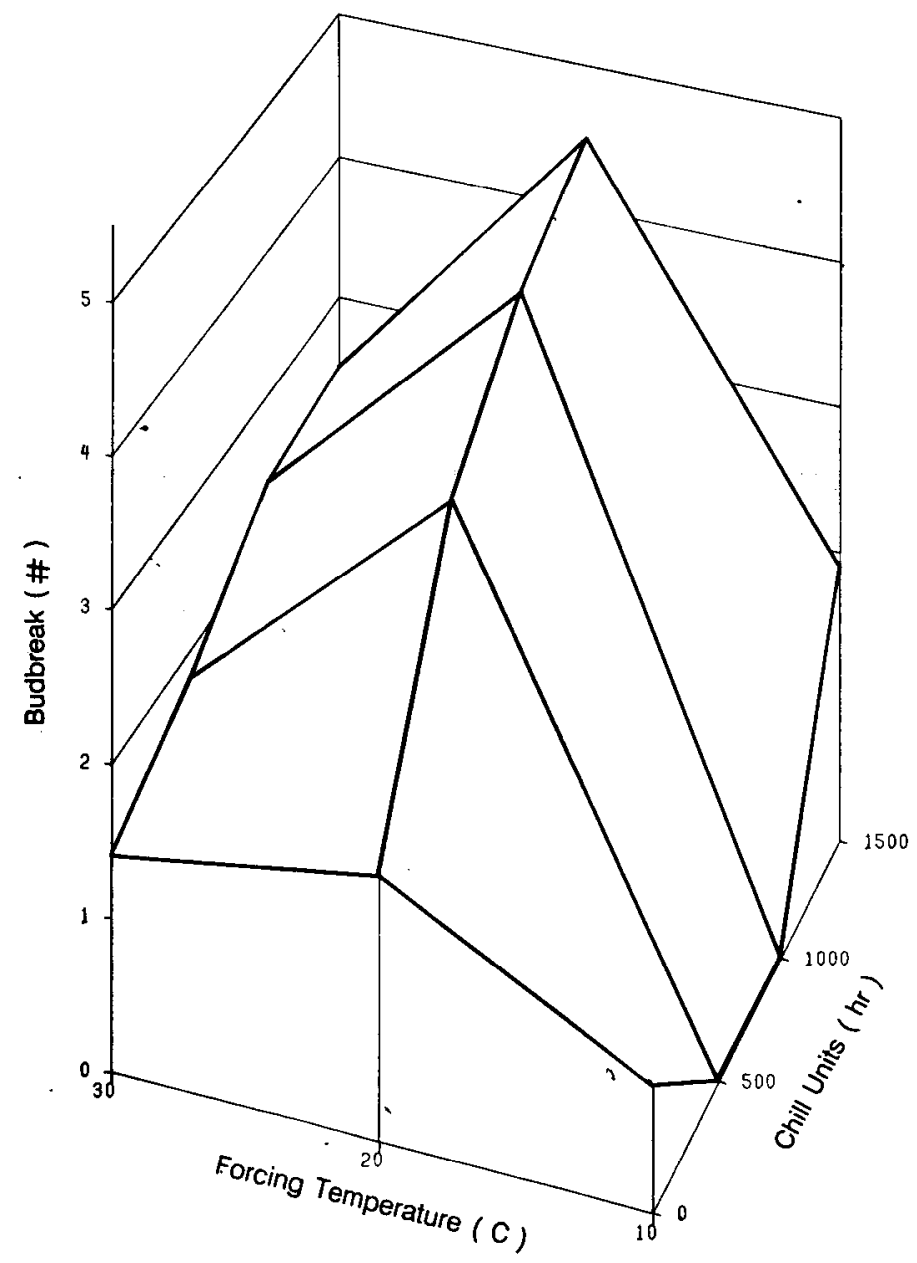

Fig. 1. Budbreak (BB) of apple trees after receiving 0, 500, 1000, or 1500 chilling hours $(\mathrm{C})$ and being forced $(\mathrm{F})$ for 21 days at 10, 20 , or $30 \mathrm{C}$. Response surface regression: $\mathrm{BB}=-7.2+(1.5 \mathrm{E}-$ $3) \mathrm{C}+0.9 \mathrm{~F}-3.3 \mathrm{C}^{2}+(1.3 \mathrm{E}-5) \mathrm{C} \times \mathrm{F}-(2.2 \mathrm{E}-2) \mathrm{F}^{2}, R^{2}$ $=0.71 * * *$.

treatment had no significant effect on respiration after $2 \mathrm{hr}$ (unpublished data). Root and shoot respiration were measured as $\mathrm{CO}_{2}$ evolution after equilibration to ambient temperature for 24 hr. Smakman and Hofstra (1982) found that in Plantago, shortterm changes in respiratory metabolism after a shift in temperature, up or down, had stabilized in $<24 \mathrm{hr}$. Plant material was sealed in the 100-ml test tubes with moist filter paper and $\mathrm{CO}_{2}$ levels determined after $2 \mathrm{hr}$ by gas chromatography using a molecular sieve $(13 \mathrm{x})$ column at $50 \mathrm{C}$ with a thermal conductivity detector with helium as a carrier gas. Respiration before $\mathrm{CO}_{2}$ measurement occurred in the dark at 5, 10, 20, and 30C (respiration temperatures) in the same growth chambers used for chilling and forcing. Fresh weights of the tissue were taken and all respiration data were based on fresh weight.

$\mathrm{Q}_{10}$ values were calculated as the ratio of respiration rate at $20 \mathrm{C}$ divided by the rate at $10 \mathrm{C}$. Ea were calculated from the slope of the Arrhenius plot of Log respiration rate vs. the reciprocal of degrees Kelvin, thus, $\mathrm{Ea}=2.3 \mathrm{R}$ (slope), where $\mathrm{R}$ equals the gas constant $\left(1.987 \mathrm{cal} \cdot \mathrm{mol}^{-1} \cdot \mathrm{K}^{-1}\right)$ and $\mathrm{Ea}$ is expressed in kilocalories per mole (Raison, 1980). Response surfaces for respiration, budbreak, and root rating were drawn from the means using SAS Graph and regression analysis done on the raw data using the SAS Response Surface Regression Procedure (PROC RSREG, SAS Institute, Cary, N.C.).

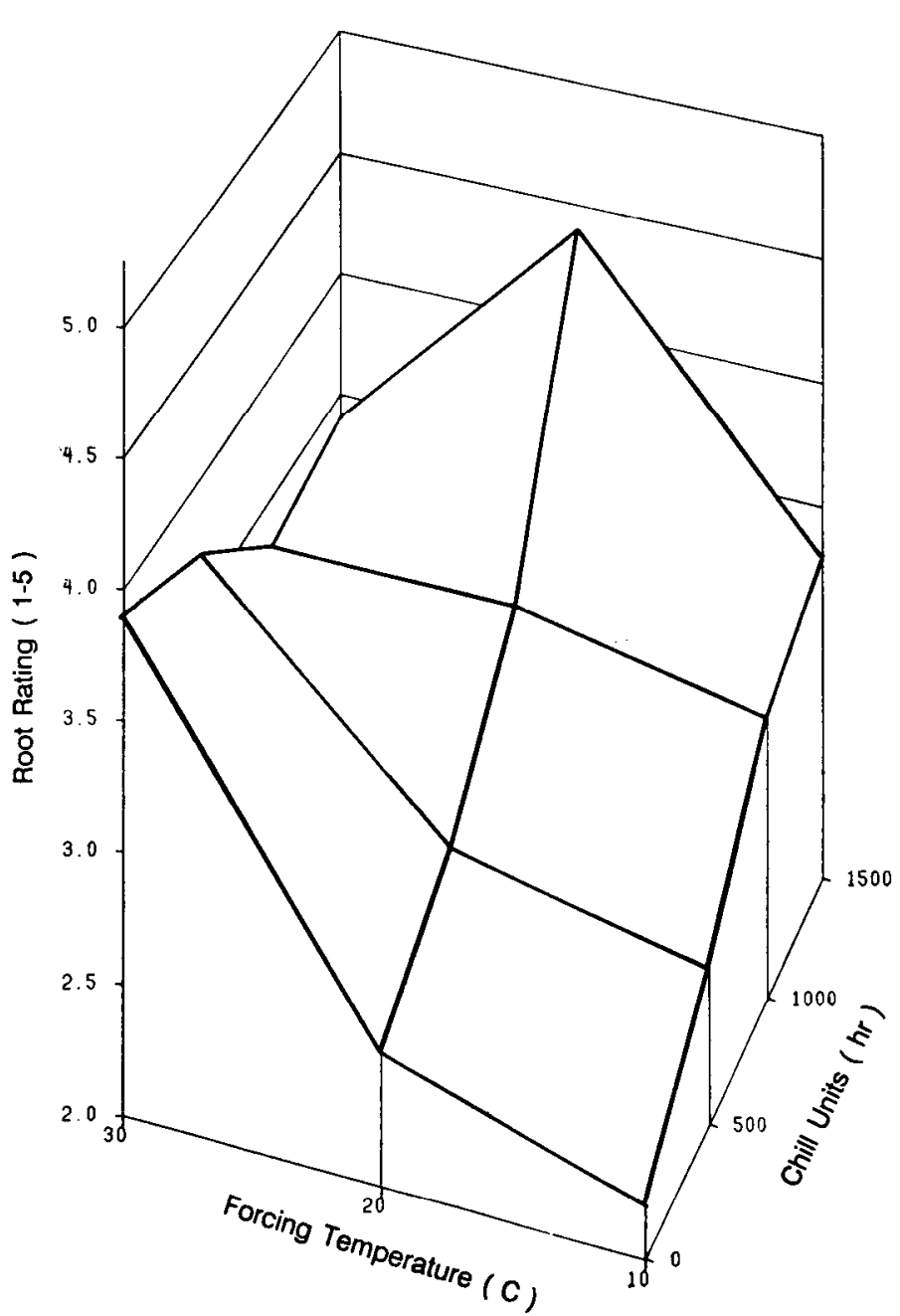

Fig. 2. Root rating (RR) of apple trees treated as in Fig. 1. Response surface regression: $\mathrm{RR}=0.8+(1.1 \mathrm{E}-3) \mathrm{C}+0.1 \mathrm{~F}+(3.3 \mathrm{E}$ $-7) \mathrm{C}^{2}-(3.7 \mathrm{E}-5) \mathrm{C} \times \mathrm{F}-(4.2 \mathrm{E}-4) \mathrm{F}^{2}, R^{2}=0.67 * * *$.

\section{Results}

Budbreak and new root growth. Budbreak and root rating after 21 days of forcing were significantly affected by chilling hours, forcing temperature, and the interaction of these factors. Budbreak increased with chilling at each forcing temperature but showed its maximum response at 20C forcing with some depression at 30C (Fig. 1), indicating a forcing temperature optimum for budbreak of $\approx 20 \mathrm{C}$. Root rating increased with chilling after forcing at 10 and $20 \mathrm{C}$, with a peak at $20 \mathrm{C}$ after $1500 \mathrm{hr}$ of chilling (Fig. 2). However, with 30C forcing, root growth rating was relatively high after 0 and $500 \mathrm{hr}$ of chilling and then decreased with further chilling (Fig. 2). Apparently, high temperatures (30C) can induce root growth while being ineffective at forcing unchilled buds to break. However, maximum budbreak and root rating did occur after the same treatments, i.e., $1500 \mathrm{hr}$ of chilling and 20C forcing.

Shoot and root respiration. Shoot respiration was significantly affected by chilling hours, forcing temperature, respiration temperature, and all two-way interactions. Shoot respiration measured immediately after removal from the chilling treatments showed an increasing temperature response after each additional $500 \mathrm{hr}$ of chilling from 0 to 1500 (Fig. 3A). The $\mathrm{Q}_{10}$ for respiration increased from 1.55 at $0 \mathrm{hr}$ of chilling to 2.60 at $1500 \mathrm{hr}(\mathrm{LSR}=0.43)$. Shoot respiration measured after 21 

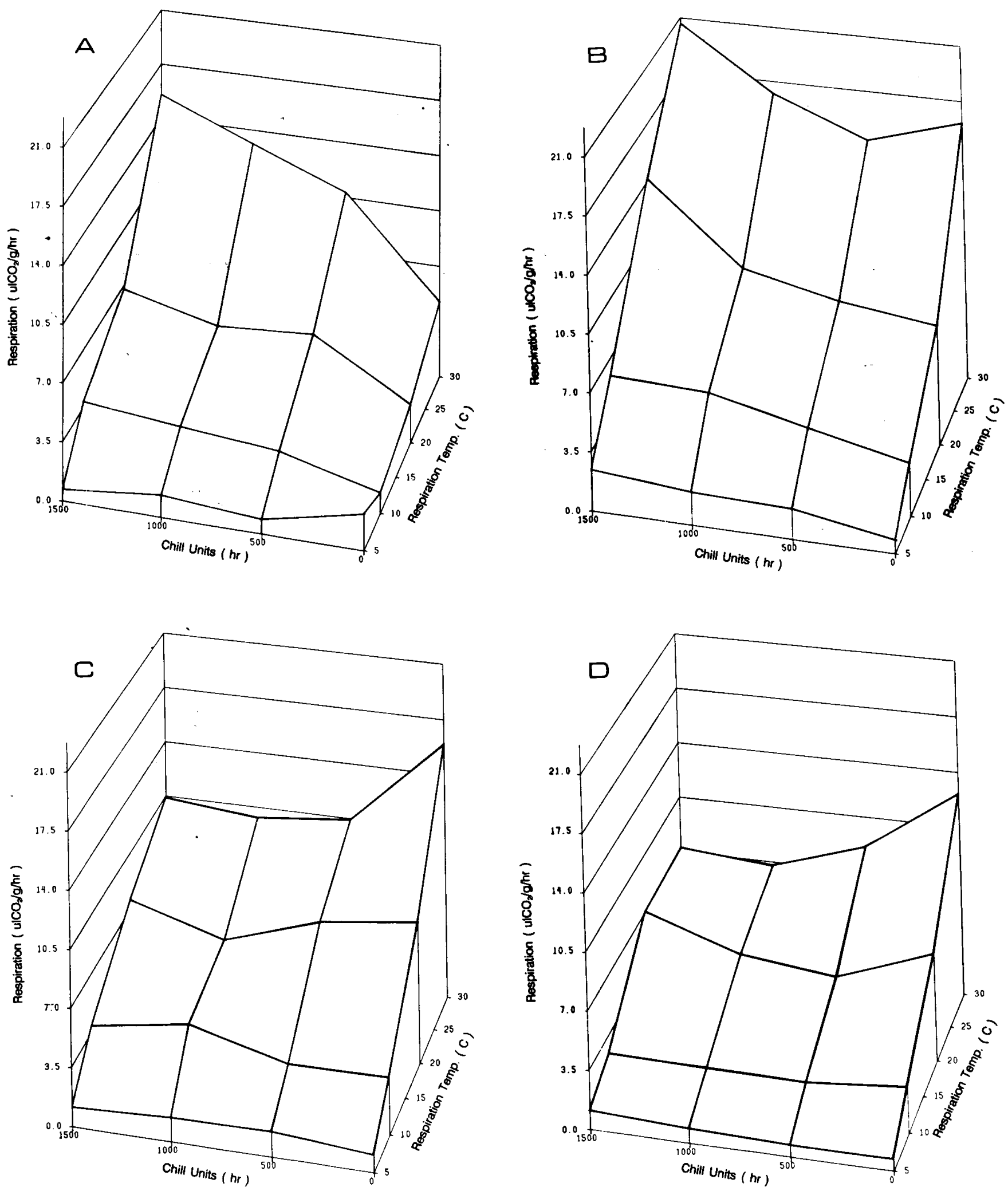

Fig. 3. (A) Shoot respiration (SR) of apple trees measured at 5, 10, 20, and 30C (T) immediately after receiving 0, 500, 1000, or 1500 chilling hours $(\mathrm{C})$. Response surface regression: $\mathrm{SR}=1.3+(1.7 \mathrm{E}-3) \mathrm{C}-(2.7 \mathrm{E}-2) \mathrm{T}-(3.6 \mathrm{E}-7) \mathrm{C}^{2}-(3.6 \mathrm{E}-5) \mathrm{T} \times \mathrm{C}+$ $(2.4 \mathrm{E}-4) \mathrm{T}_{2}, R^{2}=0.77 * * *$. (B) Shoot respiration of apple trees treated as above and forced for 21 days at 10C. Response surface regression: $\mathrm{SR}=2.9+(3.7 \mathrm{E}-3) \mathrm{C}+0.6 \mathrm{~T}-(4.6 \mathrm{E}-7) \mathrm{C}^{2}-(1.1 \mathrm{E}-4) \mathrm{T} \times \mathrm{C}-(2.5 \mathrm{E}-3) \mathrm{T}^{2}, R^{2}=0.89 * * *$. (C) Shoot respiration of apple trees treated as above and forced at 20C. Response surface regression: $\mathrm{SR}=9.4+(2.4 \mathrm{E}-5) \mathrm{C}-0.1 \mathrm{~T}+(3.5 \mathrm{E}-6) \mathrm{C}^{2}-(2.0 \mathrm{E}$ - 4) $\mathrm{T} \times \mathrm{C}+(2.4 \mathrm{E}-3) \mathrm{T}^{2}, R^{2}=0.69 * * *$. (D) Shoot respiration of apple trees treated as above and forced at 30C. Response surface regression: $\mathrm{SR}=-20.6-(5.6 \mathrm{E}-3) \mathrm{C}-0.5 \mathrm{~T}-(8.0 \mathrm{E}-6) \mathrm{C}^{2}+(4.4 \mathrm{E}-4) \mathrm{T} \times \mathrm{C}+(1.4 \mathrm{E}-2) \mathrm{T}^{2}, R^{2}=0.71 * * *$. 

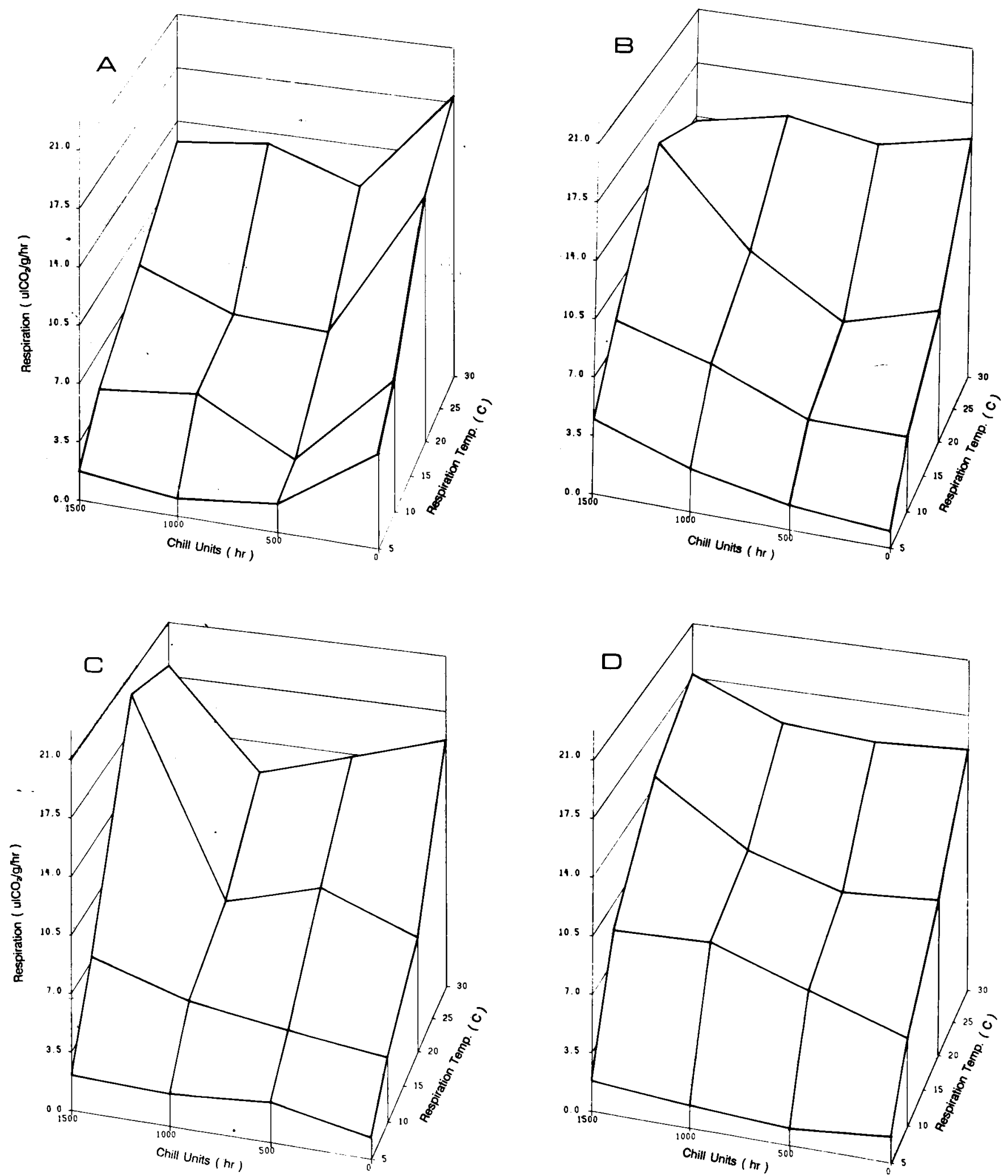

Fig. 4. (A) Root respiration (RR) of apple trees measured at 5, 10, 20, and 30C (T) immediately after receiving 0, 500, 1000, or 1500 chilling hours (C). Response surface regression: $R R=0.6+(2.2 \mathrm{E}-3) \mathrm{C}+(4.5 \mathrm{E}-2) \mathrm{T}+(5.1 \mathrm{E}-7 \mathrm{C})^{2}-(1.0 \mathrm{E}-4) \mathrm{T} \times \mathrm{C}-(3.8 \mathrm{E}-$ 4) $\mathrm{T}^{2}, R^{2}=0.59 * * *$. (B) Root respiration of apple trees treated as above and forced for 21 days at 10C. Response surface regression: RR $=9.1+(6.9 \mathrm{E}-4) \mathrm{C}+0.7 \mathrm{~T}+(9.1 \mathrm{E}-7 \mathrm{C})^{2}+(4.4 \mathrm{E}-5) \mathrm{T} \times \mathrm{C}+(1.8 \mathrm{E}-2) \mathrm{T}^{2}, R^{2}=0.54 * *$. (C) Root respiration of apple trees treated as above and forced at $20 \mathrm{C}$. Response surface regression: $\mathrm{RR}=-2.3+(2.8 \mathrm{E}-3) \mathrm{C}+0.4 \mathrm{~T}+(4.1 \mathrm{E}-6) \mathrm{C}^{2}-(2.3 \mathrm{E}-$ $4) \mathrm{T} \times \mathrm{C}-(5.9 \mathrm{E}-3) \mathrm{T}^{2}, R^{2}=0.62 * *$. (D) Root respiration of apple trees treated as above and forced at 30C. Response surface regression: $\mathrm{RR}=15.2-(1.5 \mathrm{E}-2) \mathrm{C}+0.4 \mathrm{~T}+(6.9 \mathrm{E}-6) \mathrm{C}^{2}+(2.1 \mathrm{E}-4) \mathrm{T} \times \mathrm{C}-(1.0 \mathrm{E}-2) \mathrm{T}^{2}, R^{2}=0.59^{*}$. 

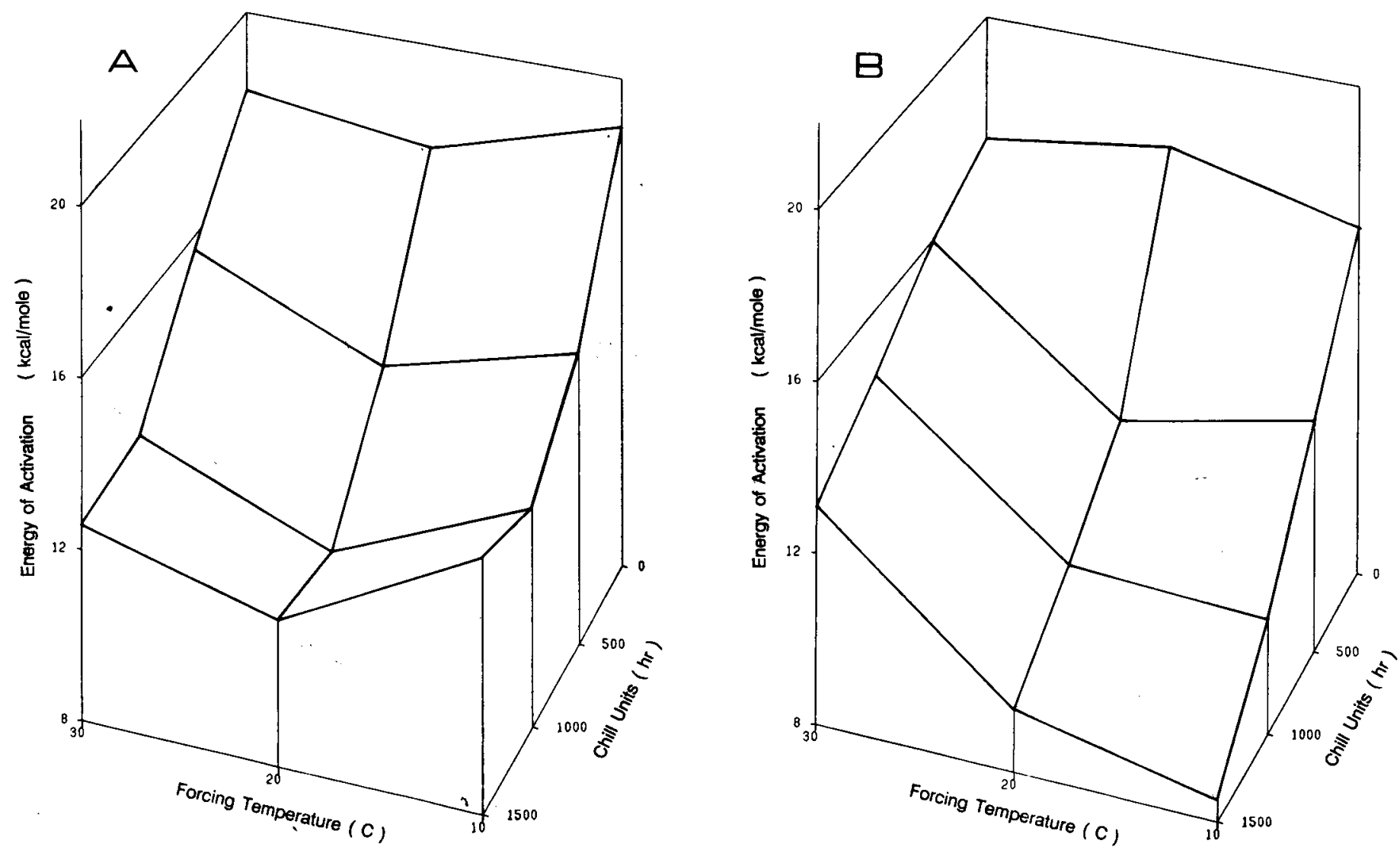

Fig. 5. (A) Ea for shoot respiration of apple trees after receiving 0, 500, 1000, or 1500 chilling hours (C) and being forced (F) for 21 days at 10,20 , or $30 \mathrm{C}$. Response surface regression: $\mathrm{Ea}=25.3+(6.2 \mathrm{E}-3) \mathrm{C}-0.9 \mathrm{~F}+(1.2 \mathrm{E}-6) \mathrm{C}^{2}+(6.3 \mathrm{E}-6) \mathrm{C} \times \mathrm{F}+(7.2 \mathrm{E}-$ 2) $\mathrm{F}^{2}, R^{2}=0.81^{* * *}$. (B) Ea for root respiration of apple trees (rested as above. Response surface regression: $\mathrm{Ea}=21.0+(7.3 \mathrm{E}-3) \mathrm{C}$ $-0.4 \mathrm{~F}+(9.2 \mathrm{E}-5) \mathrm{C}^{2}-(6.1 \mathrm{E}-4) \mathrm{C} \times \mathrm{F}+(2.9 \mathrm{E}-2) \mathrm{F}^{2}, R^{2}=0.79 * * *$

days of forcing at 10,20 , or $30 \mathrm{C}$ showed a significant change in its response to temperature depending on the forcing temperature (Fig. 3 B-D). Forcing at $10 \mathrm{C}$ after each chilling treatment resulted in an increase in the temperature response (Fig. $3 B$ ), with the highest $Q_{10}(2.62)$ measured being on trees chilled $1500 \mathrm{hr}$ and forced at $10 \mathrm{C}$. However, forcing at 20 or $30 \mathrm{C}$ after each chilling treatment, except $0 \mathrm{hr}$, resulted in a reduction in the respiration temperature response $\left(\mathrm{Q}_{10}\right)$ (Fig. $3 \mathrm{C}$ and $\mathrm{D}$ ). The lowest $\mathrm{Q}_{10}(1.96)$ for shoot respiration after forcing was with $1500 \mathrm{hr}$ of chilling and 30C forcing (Fig. 3D).

Root respiration was significantly affected by chilling hours, respiration temperature, and the two-way interaction. Forcing temperature did not have an effect on root respiration. Root respiration after 0 chilling $\mathrm{hr}$ and no forcing showed a strong response to temperature, unlike shoot respiration, with a $\mathrm{Q}_{10}$ of 2.26 (Fig. 4A). However, after $500 \mathrm{hr}$ of chilling or more, the temperature response diminished (Fig. 4A), with an average $\mathrm{Q}_{10}$ of 1.93 (LSR $=0.39)$. Although forcing temperature had no effect on root respiration response to temperature, chilling hours received before forcing did affect the response (Fig. 4 B-D). Average $\mathrm{Q}_{10}$ values across forcing temperature were 2.11, 2.02, 1.77 , and 2.23 for $0,500,1000$, and $1500 \mathrm{hr}$ of chilling, respectively. Thus, the temperature response of root respiration after forcing at 20 or $30 \mathrm{C}$ was different than for shoot respiration, with the root becoming more responsive when chilling was satisfied (1500 hr) and the shoot less responsive (Fig. $3 \mathrm{C}$ and $\mathrm{D}$ and $4 \mathrm{C}$ and $\mathrm{D})$.

Shoot and root energy of activation. The Ea for shoot and root respiration were significantly affected by chilling hours, forcing temperature, and the interaction of these factors. After 0 chilling hours, Ea remained high for both shoot and root respiration, regardless of forcing temperature, with an average Ea of 18.1 and $17.0 \mathrm{kcal} \cdot \mathrm{mol}^{-1}$ for shoot and root, respectively (Fig. $5 \mathrm{~A}$ and B). With increased chilling hours, Ea decreased significantly for both shoot and root respiration at all forcing temperatures, reaching an average Ea of 12.6 and 10.0 after 1500 chilling hours for shoot and root, respectively (Fig. 5 A and B). Shoot Ea decreased to its lowest point after 20C forcing and root Ea decreased most after 10C forcing, possibly indicating a lower optimum forcing temperature for roots than shoots.

\section{Discussion}

The $\mathrm{Q}_{10}$ of plant respiration is reported to be $\approx 2.0$ and the $\mathrm{Ea} \approx 12 \mathrm{kcal} \cdot \mathrm{mol}^{-1}($ Lambers, 1985$)$. There is extensive literature indicating that these values can change significantly with temperature, particularly in response to chilling injury (Raison, 1980 ), but little information is available regarding $Q_{10}$ and $E a$ changes relating to normal seasonal development. Breeze and Elston (1978) reported a higher $\mathrm{Q}_{10}$ and Ea in winter than in summer for Vita faba and Sorghum vulgare plants, and Wager (1941) found a similar condition in four arctic species. However, a decrease in these values associated with release from dormancy and renewed growth has not been documented.

Since Ea is a measure of the energy needed to move a reaction or pathway forward, it is not unexpected that Ea for respiration would be lower during active growth than in dormancy. The 
biochemical explanation for this change, however, is open to much speculation. A change in Ea for multienzyme reactions might occur due to alterations in the substrate $\mathrm{Km}$ or changes in the rate limiting step; however, changes in respiratory Ea have been shown to not be attributable to these causes (Raison, 1980). It appears that, at least with tropical plants at low temperatures, changes in respiratory Ea are induced by alterations in the membrane lipid structure leading to changes in the membrane-bound respiratory enzymes (Raison, 1980). Perhaps the decrease in respiratory Ea after chilling is a result of low-temperature membrane alterations that either induce or predispose changes in the enzymes involved. Changes in membrane composition and structure during dormancy and budbreak have been reported for mulberry (Yoshida, 1984, 1986) and Wang and Faust (1987) have implicated membrane alterations as a possible mechanism involved in regulating time of bloom for fruit trees.

Another possible explanation for the observed decrease in respiratory Ea after chilling is a shift in the source of the $\mathrm{CO}_{2}$ evolved. Because the Ea measured is actually that of $\mathrm{CO}_{2} \mathrm{ev}-$ olution rather than mitochondrial respiration per se, it is an average for all pathways that evolve $\mathrm{CO}_{2}$. The Ea of soluble enzyme systems, such as glycolysis, are generally much lower than those of membrane-bound systems, i.e., $\approx 9 \mathrm{kcal} \cdot \mathrm{mol}^{-1}$ rather than 12 (Raison, 1980). The observed decrease in Ea might represent a shift to higher proportion of $\mathrm{CO}_{2}$ evolved from soluble than from bound systems. For example, the pentose phosphate pathway, which provides substrates for synthesis of many secondary compounds, may increase its contribution to overall $\mathrm{CO}_{2}$ evolution.

The study reported here provides evidence for chilling during dormancy having an effect on how respiration responds to temperature and indicates a change in carbon metabolism $\left(\mathrm{CO}_{2} \mathrm{ev}-\right.$ olution) associated with dormancy release.

\section{Literature Cited}

Barskaya, E.N. and E.Z. Oknina. 1959. The role of nucleic acids in the growth processes and bud dormancy of fruit crops. Soviet Plant Physiol. 6:470-476.

Breeze, V. and J. Elston. 1978. Some effects of temperature and substrate content upon respiration and the carbon balance of field beans (Vicia faba L.). Ann. Bet. 42:863-876.

Butler, D.R. and J.J. Landsberg. 1981. Respiration rates of apple trees, estimated by $\mathrm{CO}_{2}$-efflux measurements. Plant Cell \& Env. 4:153159.

Chen, S.S.C. and J.E. Varner. 1970. Respiration and protein synthesis in dormant and after-ripened seeds of Avena fatua. Plant Physiol. 46:108-112.

Cox, T.L. 1975. Seasonal respiration rates of yellow-poplar roots by diameter classes. For. Sci. 21:185-190.
Hansen, P. 1971. "C-Studies on apple trees: VII. The early seasonal growth in leaves, flowers and shoots as dependent upon current photosynthates and existing reserves. Physiol. Plant. 25:469-473.

Holthausen, R.S. and M.M. Caldwell. 1980. Seasonal dynamics of root system respiration in Atriplex confertifolia. Plant and Soil 55 :307317.

Lambers, H. 1985. Respiration in intact plants and tissues: Its regulation and dependence on environmental factors, metabolism and invaded organisms, p. 418-473. In: R. Deuce and D.A. Day (eds.). Higher plant cell respiration. Springer-Verlag, New York.

Perry, T.O. 1971. Dormancy of trees in winter. Science 171:29-36.

Priestly, C.A. 1962. The location of carbohydrate resources within the apple tree. Proc. XVIth Intl. Hort. Congr. 3:319-327.

Quinlan, J.D. 1969. Mobilization of " $\mathrm{C}$ in the spring following autumn assimilation of ${ }^{14} \mathrm{CO}_{2}$ by an apple rootstock. J. Hort. Sci. 44: 107110.

Raison, J.K; 1980. Effect of low temperature on respiration, p. 613626. In: D.D. Davies (cd.). The biochemistry of plants. vol. 2. Academic, New York.

Samish, R.M. 1954. Dormancy in woody plants. Annu. Rev. Plant Physiol. 5:183-204.

Shiroya, T., G.R. Lister, V. Slankis, G. Krotokov, and G.D. Nelson. 1966. Seasonal changes in respiration, photosynthesis, and translocation of ${ }^{14} \mathrm{C}$-labeled products of photosynthesis in young Pinus strobus L. plants. Ann. Bot. 30:81-91.

Smakman, G. and R.J.J. Hofstra. 1982. Energy metabolism of Plantago lanceolata, as affected by change in "root temperature. Physiol. Plant. 56:33-37.

Strain, B.R. 1969. Seasonal adaptations in photosynthesis and respiration in four desert shrubs growing in situ. Ecology 50:51 1-5 13 .

Titus, J.S. and S.M. Kang. 1982. Nitrogen metabolism, translocation, and recycling in apple trees. Hort. Rev. 4:204-246.

Wager, H.G. 1941. On the respiration and carbon assimilation rates of some arctic plants as related to temperature. New Phytol 40: 119.

Wang, S.Y. and M. Faust. 1987. Metabolic activities during dormancy and blooming of deciduous fruit trees. Israel J. Bet. 37:227-243.

Wang, S. Y., M. Faust, and G.L. Steffens. 1985. Metabolic changes in cherry flower buds associated with breaking of dormancy in early and late blooming cultivars. Physiol. Plant. 65:89-94.

Wood, B.W. 1983. Changes in indoleacetic acid, abscisic acid, gibberellins, and cytokinins during bud break in pecan J. Amer. Soc. Hort. Sci. 108:333-338.

Yoshida, S. 1984. Chemical and biophysical changes in the plasma membrane during cold acclimation of mulberry bark cells (Morus bombysis Koidz. CV. Goroji). Plant Physiol. 76:257-265.

Yoshida, S. 1986. Reverse changes in plasma membrane properties upon deacclimation of mulberry trees. Plant Cell Physiol. 27:83-89.

Young, E., Y. Motomura, and C.R. Unrath. 1987. Influence of root temperature during dormancy on respiration, carbohydrates, and growth resumption in apple and peach. J. Amer. Soc. Hort. Sci. 112:514519. 